\title{
Corruption: Does Environmental Damage Constitute State's Financial Loss?
}

\author{
Bambang Sugiri \\ Faculty of Law \\ Universitas Brawijaya \\ Malang, Indonesia \\ bambang.sugiri@ub.ac.id
}

\author{
Alfons Zakaria \\ Faculty of Law \\ Universitas Brawijaya \\ Malang, Indonesia \\ alfons@ub.ac.id
}

\begin{abstract}
The purpose of this paper is to analyze the equalization of environmental damage with the financial loss of the State by the KPK's prosecutor in indicting the perpetrators of corru ption charged under article 2 and 3 of Act No. 31 Year 1999. The decision of the Corruption Court in Nur Alam case stating that the accused has been proven in committing corruption which is detrimental to the State's financial or economy, is a new breakthrough in handling corruption cases related to environmental damage. For the first time, the KPK's Prosecutor equates environmental damage with financial or economic losses of the $S$ tate in Article 2 and Article 3. This paper will argue that the KPK's Prosecutor has used both the analogy and extensive interpretation. This article then explains the reasons, in which original definition of the $S$ tate financial loss does not cover environmental damage. Secondly, the existence of Article 4 of the law on corruption eradication shows that environmental damage is not included in the $S$ tate financial loss. The last is that the law maker does not have the idea that environmental damage is induded in the State financial loss.
\end{abstract}

Keywords-Corruption, KPK, Financial Loss, Environmental Damage

\section{INTRODUCTION}

The Corruption Crime Court in Central Jakarta on March 28, 2018 has imposed sanctions on Nur Alam as the nonactive Governor of Southeast Sulawesi Province with 12year imprisonment and a fine of 1 billion rupiah. Nur Alam was declared legally and convincingly to have committed criminal corruption indicted by KPK Prosecutor, which is in line with Article 2 Paragraph (1) or Article 3 of Act Number 31 Year 1999 concerning the Eradication of Corruption. The KPK's Prosecutors charged that the granting approval to increase the IUP of Exploration into IUP of Production Operation to PT Anugerah Harisma Barakah (AHB) had caused environmental damage. The environ mental damage is considered to have harmed the State finance of 4.3 trillion rupiah based on calculations based on the Regulation of the Minister of Environment No. 7 Year 2014 on Environ mental Losses Due to Pollution and/or Environmental Degradation. Based on this argument, the Prosecution referred to Article 2 Paragraph (1) or Article 3 to indict Nur Alam as the accused for misusing authority in his position to benefit himself or others or a corporation to the detriment of the State's finances.

The application of environmental damage as a form of State's financial loss in the case of Nur A lam is the first time conducted by KPK in handling corruption cases [1]. The
KPK has not previously used environmental damage as a form of financial loss of the State or State economy as set forth in Article 2 Paragraph (1) and Article 3 of the AntiCorruption Eradication Act. The question then rises whether including environmental damage as a form of State's financial loss is against legality principle, especially the interpretation of analogy.

This paper will argue that when the Prosecutor equates environmental damage to the State's financial losses, the Prosecutor has used both the analogical interpretation and also extensive interpretation. This paper will initially cover an analogy and extensive interpretation. This paper then conveys the reason why equating environmental destruction with the State's financial loss, is an analogy interpretation or also an extensive interpretation. The first reason is that the original notion of the State's financial loss does not include environmental damage. Secondly, the existence of Article 4 of the Law on corruption eradication shows that environmental damage is not included in the State's financial loss. The latter that when drafting the anti-corruption legislation, the legislator does not have the idea that environmental damage is included in State's financial losses. Finally, this article will recognize that when a court decision has been is sued, the decision becomes a law.

\section{DISCUSSION}

\section{A. Extensive analogy and interpretation}

The principle of legality or nullum delictum nulla poena sine praevia lege poenali means no offense, no punishment without a pre-existing penal provisions or nullum delictum nulla poena sine lege stricta means no offense, no punishment without exact law. This principle emphasizes that penal law must be strictly construed and there must not be a retroactive effect[2], and forbids analogies[3]. According to Moeljatno, from the principle of legality formulation, it can be concluded that [4]:

a. There are no actions to be punished in the law.

b. Analogy must not be used to determine the existence of criminal acts.

c. Criminal law does not apply retroactively.

The purposes of the principle of legality are the protection of individual human rights, promoting legitimacy of governance, protecting the structure of democratic governance and promoting the purposes of criminalization[5]. The most important goal of this princip le is to protect the human rights for everyone. Every person's 
rights must be protected, including the perpetrator, from every legal process by the State in handling criminal cases. The State through law enforcement agencies is prohibited from using its authority by violating the prescribed legal principles.

One that is forbidden when embracing the principle of legality is the interpretation of analogies. Analogical interpretation provides an interpretation of a rule of law by giving the words in the rule in accordance with its legal principle, so that an actual event can not be entered then it is deemed to be in accordance with the sound of the rule[6]. Analogy in practice is often equated with extensive Analogy in practice is often equated with extensive interpretation. In Indonesia itself, the interpretation of analogy is prohibited to be practiced in the field of criminal law because it is contradictory to the legality principle contained in Article 1 paragraph (1) of the Criminal Code. Judges are prohibited by using an analogy of incorporating events into the realm of criminal law, but it is not forbidden to use extensive interpretations, although in essence the analogy is expansive as well as extensive interpretation [7].

Through the extensive interpretation of words in the legislation extends to find new meaning in accordance with the case faced by not removing the essence of the existence of the rule. This is as described in the Black's Law dictionary "the art or process of discovering and ascertaining the meaning of a statute, will, contract, or other written documents. The discovery and representation of the true meaning of any signs are used to convey ideas [8]".

The purpose of the extensive interpretation is to provide a new understanding of a term in the rule of law which, according to Christianto, is based "that in every rule of law (rechtsregel) it contains a legal rule (rechtsnorm) in which there is a proposition about the forbidden thing [9]". Through this extensive interpretation, it is hoped that a meaning that goes beyond grammatical interpretation can be figured out so that there is no impunity.

This method is used when the judge considers that the existing legislation has not been clearly regulated in relation to the legal event taking place, so the judge needs to extend the meaning contained in the law[10]. One example of a case that may be a milestone of extensive interpretation is the case of an electric arrest in 1921, in which Hoge Raad then interpreted electricity as a stolen item, whereas the term of the goods at that time referred only to tangible goods [9]. So it can be said that when the definition of goods that at that time was only restricted to tangible goods and can change hands, while now the meaning is extended to goods interpreted as intangible objects.

Based on the above description, it can be emphasized that the act of enforcing an act or equating a term into another term that was not previously included in an act or initial term is a form of analogy and extensive interpretation.

\section{B. Definitions State's Financial Losses Do Not Cover Environmental Damage}

There are various perspectives to define the State's financial losses. In the positive law in Indonesia there are at least two perspectives that can be used to interpret the financial losses of the State. The first is the perspective of criminal law specifically mentioned in Act no. 31 Year 1999 jo. Act no. 20 Year 2001 on the Criminal Act of Corruption.
The second is in the perspective of administrative law as mentioned in Act no. 17 Year 2003 on State Finances, Act no. 1 of 2004 on the State Treasury, and Act no. 15 Year 2006 on the State Audit Board.

The State's financial losses in the dimensions of criminal law are in the criminal acts of corruption as regulated in Articles 2.3 and 4 of Act Number 31 Year 1999 jo. Act Number 20 Year 2001. In the criminal act, the State's financial loss becomes one of its elements. However, Act No. 31 Year1999 jo. Act No. 20 Year 2001 does not provide a rigid definition or explanation of financial loss of the country. The explanation of State's finance is only stated in the commentary of the Law[11]:

" The State finance in question shall be the entire wealth of the State in whatever form, separated or undivided, including all parts of the State property and all rights and obligations arising out of:

(a) Being in the control, administration and accountability of officials of State institutions, both at the central and regional levels;

(b) in the possession, control and accountability of StateOwned Enterprises / Regional-Owned Enterprises, foundations, legal entities, and companies that include State capital, or companies that include third party capital under an agreement with the State"

The term financial loss of the State is also defined in the perspective of administrative law and regulated in detail in Law no. 1 Year 2004 on State Treasury and Law no. 15 Year 2006 on the State Audit Board. Both provide the same definition as to what is a State financial loss in which State or regional losses are lack of money, securities, and goods, which are real and inevitable in number as a result of unlawful acts either intentionally or negligently[11]. Whereas pursuant to Article 1 number 7 of Law Number 15 Year 2006 concerning the State Audit Board, State Finances are all the rights and obligations of the State which can be assessed with money, as well as everything in the form of money or in the form of goods that can be used as State property due to the exercise of the rights and such obligations.

According to other regulations that also define the State finance, specifically Law No. 17 of 2003 on State Finance, State Finance is all the rights and obligations of the State that can be assessed with money, as well as everything in the form of money or in the form of goods that can be owned by the State since the exercise of such rights and obligations. The above understanding is the same as the definition of State finances given Law Number 15 Year 2006 about the State Audit Board.

To understand the meaning of the State financial loss, it must be known the meaning of the loss itself which means to bear or suffer loss is related to something that is considered to be a loss such as damage, and losing, or decreasing in quantity. So the term finance brings broad definition. That is, the meaning of the definition of State finance is argumentum a contrario from the definition of State finances according to the explanation of the law. This very broad formulation intends to anticipate the State financial deviation[12]. According to Artidjo Alkostar, State finance includes all the wealth of the country including money and something of value. In judicial practice, the financial loss of the country is 
understood by the meaning of diminishing State property or increasing State obligations without equal achievement caused by unlawful acts .

Central Jakarta District Court's Verdict Number: 52/Pid.Sus/TPK/ 2013/PN.Jkt.Pst. gives the definition that disadvantaging is the same as being a loss or becoming reduced. What is meant by the element of disadvantaging State's finance is the same as being a loss of State finance or reduced State finance. With regard to the formulation of State finances as referred to in Law Number 31 Year 1999, State finance loss may take form of[12]:

1. State/Regional source/wealth (could be in the form of money, goods) expenditures that should not be is sued

2. State/Regional source/wealth expenditures that surpas s the valid criteria

3. Loss of State/Regional sources/wealth that should be received

4. Lower State/Regional source/wealth income than one that should be received

5. Emergence of State/regional obligation that should not exist

6. Emergence of greater State/regional obligation than it should be

7. Loss of State/regional right that it should have according to the existing regulation

8. Less State/regional right than it should have received

While related to State economy, the explanation within Law number 31 year 1999 on Criminal Law of Corruption provides definitions on the meaning of the economy of the State where the economy of a country is an economic life compiled as a joint effort based on the principle of kinship or society effort independently based on government policy both at central or regional level in accordance with the provisions of applicable legislation that aims to provide benefit, prosperity, and welfare to the life of the society.

Meanwhile, the definition of State losses is regulated in Law number 1 Year 2004 on State Treasury, Article 1 paragraph 22 explains "State/regional losses are the lack of money, securities/valuable documents, and goods that are legit and certain in number as a result of unlawful acts either intentionally or negligently"[13]. Based on the definition above, the elements of State losses are:

1) State losses are the decrease of State finance in the form of valuable money, State property of the supposed amount and/or the value

2) The shortcoming in the State's finance has to be legit and certain in number or in other words the losses have actually occurred with the amount of loss that can definitely be determined, thus the loss of the State is only an indication or a potential loss

3) Such losses are due to unlawful acts, whether intentionally or negligently; elements of unlawful act must be proven accurately and appropriately .

The meaning of disadvantaging the State is an act that may contribute to why State losses occur, direct or indirectly, in a joint effort of the principle of kinship or society's independent effort based on government policy aimed to provide benefit, prosperity, and welfare to all life of the society.
In addition, in consideration of the enactment of Act Number 3 Year 1997 and Act Number 31 Year 1999 on the Eradication of Corruption, it is Stated that Criminal Acts of Corruption can hamper the growth and sustainability of national development that requires high efficiency. Furthermore, with the national development being hampered, it can lead to slow growth of State economy. The example of corruption case that could harm State economy is the case of Beef Imports, where the Ministry of Agriculture once limited the import quota for beef, but was suspected to have manipulated some data so that the import quota at that time was expected to be raised. This will certainly affect Indonesia's economy policies, disrupt, and potentially harm the country's economy.

Description regarding the definition of State's financial or economic loss above does not indicate environmental damage as part of the financial or economic losses of the State. The KPK's Prosecutor, therefore, when defined environmental damage as a State's financial or economic loss, seems straining to make what the accused did, leading to environmental damage and punishment. It is hard to deny that the KPK's Prosecutor has conducted analogical interpretation. "...analogy goes beyond statutory interpretation in that it explicitly recognizes criminality outside of a statute"[5].

\section{Article 4 in the Eradication of Corruption Act Shows that Environmental Damage is Not Included in the State's Financial Losses}

Article 4 of the Eradication of Corruption Act states that "The return of the State finance or econo mic losses does not abolish the imprisonment of the criminal actor as refer red to in Articles 2 and 3." This article indicates that the financial losses of the State or the State economy can be restored by the doer of the corruption before or when the case is processed. Based on the indication, environmental damage is not one form of State's financial or economic loss. This is based on the fact that environmental damage takes a long time to recover.

The Environmental Liability Regulations 2008 divides the Environmental Damage into three types namely; 1) Damage to habitat in nature and protected species, 2) Damage impacting on Ecology, 3) Contamination that potentially threats the human health and safety[14]. In Indonesia, the definition of environmental damage is stated in Article 1 Act Number 32 Year 2009 on Environmental Protection which reads as follow: "Environmental damage is a direct and/or indirect change in the physical, chemical, and/or biological properties of the environment beyond the standard criteria of environmental degradation."

In this case, the standard criteria for environmental damage are the limits of changes in physical, chemical, and/or biological properties of the environment that can be tolerated by the environment to remain able to preserve its functions.[15]. The standard criteria for environmental damage serves as an indicator to measure whether an environmental situation can be categorized as damaged or polluted. All regulations regarding Standard Criteria for Environmental Damage are regulated in Article 21 paragraph (1) to (5) Act Number 32 Year 2009 on Environmental Protection. 
Because of its identical definition, Environmental Damage is often likened to Environmental Pollution. Environmental Pollution is the entry or inclusion of living things, substances, energy, and/or other components into the environment by human activities to where its quality drops to certain level, resulting in the environment not functioning in accordance with its designation[16].

In terms of the provisions in the Regulation of the Minister of Environment Number 7 Year 2014 on Environmental Losses Due to Pollution and/or Environmental Damage that regulates the payment of environmental losses, the Ministerial Regulation regulates the payment of environmental losses in case of environmental dispute based on expert calculations. Whereas, Article 4 of Eradication of Corruption Act regulates returning State's financial or economic loss. The payment for environmental loss is not a form of restoring State financial or economic losses. This is because the payment is not necessarily able to restore the environment back to how it was originally before the damage occurred. In Article 4 states returning the environment back to its original condition as before the State financial or economic losses occurred.

\section{The Legislatives Do Not See Environmental Damage as a Form of State Financial Losses}

Act Number 31 Year 1999 on Eradication of Corruption then amended to Act Number 30 Year 2001 that was enacted to deal with disgraceful acts of State officials deemed to be detrimental to the State and the public. In the history of Indonesia, until such law has been established, never has there been an act of State's official that causes Environmental Damage that is considered as a criminal act of corruption that harms the finance or economy of the State. So in the minds of the drafters of the law at the time, such acts by State's official that later may cause environmental damage are considered as corruption.

Efforts to eradicate corruption must be done optimally and thoroughly. However, as a State law that upholds the principle of legality in criminal cases, law enforcer must implement the existing law in handling criminal cases. This is to guarantee that the rights of the perpetrators are not violated by the State. The government, in promoting legality principle and refusing analogical and extensive interpretation when handling criminal cases, must honor modern human rights law [5]. "...exercising analogy as an interpretative method creates in practice a new criminal norm that applies retroactively and that has never been accepted explicitly by the legislator"[17].

In addition, extensive interpretation has three potential issues for legality, namely expanding criminal liability retroactively, possibility of making wrong meaning and "possible over-deterrence of activity that is not meant to be criminalized becomes larger in an expansive interpretation system"[5]. The use of the interpretations that are prohibited in the principle of legality in handling criminal cases by law enforcement officers, where they have legal authority, is feared to harm the rights of every citizen even though it is done accidentally. The basic idea of the principle of legality is the guarantee of the protection of the rights of citizens by limiting the power of the authority through criminal law instruments [18].

\section{E. Court's Verdict is Law}

The finding of law according to Sudikno Mertokusumo "... the process of law formation by judges or other legal officers who are given the task of carrying out the law or implementing general law regulations for concrete legal events"[19]. Roscoe Pound states that in trial the judge must follow three steps: first, the judge must find law, that the judge seeks which legal rules should be applied to concrete legal events based on the existing law; second, interpret the legal rules that have been chosen; and third apply the law to the concrete case faced[20]: Article 5 paragraph 1 of Act No. 48 Year 2009 states "Constitutional judges and judges are obliged to explore, follow and understand legal values and a sense of justice that lives in society". The meaning of digging can mean that the law exists, but only has not been found, in which according to Paul Scholten the law is found in human behavior. Because of his/her behavior in the commun ity and because the law is already there, it is only to find, explore and find it[21]. From the three definitions above, it can be seen that when the judge has found the law, the decision may become a law, especially for the case.

The court verdict against Nur Alam who was found guilty and proven committing corruption in relation to the financial or economic State losses will become legally binding. Thus, it must be respected by all people. Even though as in the discussion above, there may be potential violations of citizens' rights.

\section{CONCLUSION}

Based on the discussion above, it can be concluded that the KPK prosecutor's action to equalize the environmental damage with financial or economic losses of the State in the case of corruption is a form of analogy of extensive interpretation. However, when a court decision has been is sued and becomes a permanent legal force, then the verdict has become a law. Fortunately, although what the KPK prosecutor did is contrary to the principle of legality that Indonesia's law adopts, it is in accordance with the opinion of the judge. If not, then it would have been "disaster" in law enforcement in corruption cases in Indonesia

\section{REFERENCES}

[1] Abba Gabrillin, "Pertama Kalinya KPK Menilai Kerusakan Lingkungan sebagai Kerugian Negara," 2018. [Online]. Available: https://nasional.kompas.com/read/2018/03/08/18391231/pertamakalinya-kpk-menilai-kerusakan-lingkungan-sebagai-kerugian-negara.

[2] Jerome Hall, General Principles of Criminal Law, 2i ed. the Lawbook Exchange Ltd., 2010.

[3] F. J. Gerhard Werle, Principles of International Criminal Law, 3rd ed. Oxford University Press, 2014.

[4] Moeljatno, Asas-asas Hukum Pidana. Jakarta: Rineka Cipta, 2002.

[5] Kenneth S. Gallant, The Principle of Legality in International and Comparative Criminal Law. Cambridge University Press, 2009.

[6] Sudikno Mertokusumo, Mengenal Hukum. Yogyakarta: Liberty Yogyakarta, 2007.

[7] Abintoro Prakoso, Penemuan Hukum. Yogyakarta: LaksBang PRESSindo, 206AD

[8] Black H. Campbell, Black's Law Dictionary Deluxe: Definitions of Term s and Phrases of American and English Jurispndence: Ancient 
and Modern, 6th ed. St. Paul Minn. West Publishing, 1990.

[9] Hwian Christianto, "Batasan dan Perkembangan Penafsiran Hukum dalam Hukum Pidana,” J. Trunojoyo, vol. 3, no. 2, 2010.

[10] Bagir Manan, Menegakkan Hukum Suatu Pencarian. Jakarta: Asosiasi Advokat Indonesia, 2009.

[11] Suhendar, Konsep Kerugian Keuangan negara: Pendekatan Hukum Pidana, Hukum Administrasi Negara, dan Pidana Khusus Konupsi. Malang: Setara Press, 2015.

[12] Abdul Latif, Politik Hukum. Jakarta: Sinar Grafika, 2014.

[13] S. Serbabagus, "Unsur dapat Merugikan Keuangan Negara atau Perekonomian negara pada Peertanggungjawaban Tindak Pidana Korupsi," Lex J., vol. 1, no. 1, pp. 10-11, 2017.

[14] ECOS, "What is Environmental Damage?," 2012. [Online] Available: http://www.ecos.ie/what-is-environmental-damage/. [Accessed: 27-Jul-2018].

[15] Article 1 (15) of Act Number 32 Year 2009 on Environmental
Protection and Management.

[16] Article 1 (12) of Act Number 32 Year 2009 on Environmental Protection and Management.

[17] Gabriel Hallevy, A Modern Treatise on the Principle of Legality in Criminal Law. Berlin: Springer-Verlag Berlin Heidelberg, 2010.

[18] Deni Setyo Bagus Yurehawan, Dekontruksi Asas Legalitas Hukum Pidana. Setara Press, 2014.

[19] S. M. A. Pitlo, Bab-Bab Tentang Penemuan Hukum. Bandung: Citra Aditya Bakti, 1993.

[20] Mila Karmila Adi, "Hakim sebagai Pembentuk Hukum dalam Pandangan Pragmat is Realisme bagi Kebebasan Hakim Indonesia dalam Pengambilan Putusan," J. Huk., vol. 6, no. 12, p. 128, 1999.

[21] Sudikno Mertokusumo, Bunga Rampai Ilmu Hukum. Yogyakarta: Liberty, 2010. 